\title{
REAKSI PASAR TERHADAP CHINA'S BLACK MONDAY DI BURSA EFEK INDONESIA
}

\author{
Gde Agung Satria ${ }^{1}$ \\ Luh Gede Sri Artini \\ Henny Rahyuda ${ }^{3}$ \\ ${ }^{1,2,3}$ Fakultas Ekonomi dan Bisnis Universitas Udayana (Unud), Bali, Indonesia \\ e-mail: gdeagungsatria@gmail.com
}

\begin{abstract}
ABSTRAK
Tujuan dari penelitian ini adalah untuk menguji reaksi pasar terhadap peristiwa China's Black Monday (CBM) di Bursa Efek Indonesia (BEI). Penelitian ini dilakukan pada seluruh perusahaan yang terdaftar di BEI yang tidak melakukan corporate action pada periode peristiwa. Seluruh perusahaan yang diteliti dibagi menjadi sembilan sektor yang diklasifikasikan menurut klasifikasi industri yang telah ditetapkan BEI yaitu JASICA (Jakarta Industrial Classification). Metode event study digunakan untuk menguji adanya reaksi pasar terhadap peristiwa CBM. Berdasarkan hasil penelitian terdapat reaksi pasar yang signifikan pada delapan Indeks Sektoral di Bursa Efek Indonesia yaitu Sektor Pertanian; Aneka Industri; Industri Dasar dan Kimia; Industri Barang Konsumsi; Properti dan Real Estate; Transportasi dan Infrastruktur; Keuangan; dan Perdagangan, Jasa dan Investasi sedangkan Indeks Sektor Pertambangan tidak bereaksi terhadap peristiwa CBM.
\end{abstract}

Kata kunci: abnormal return, china's black monday, event study

\begin{abstract}
This study aimed to test market's reaction of the China's Black Monday (CBM) at the Indonesian Stock Exchange (BEI). This research was conducted on all companies listed on the Stock Exchange which did not conduct corporate action in the event period. All the companies researched are divided into nine sectors and industries are classified according to the classification established by BEI called JASICA (Jakarta Industrial Classification). Event study method used to test the market reaction to the CBM. Based on the research results, there is a significant market reaction on eight sectoral index in the Indonesia Stock Exchange, namely the Agricultural Sector; Miscellaneous Industry; Basic Industry and Chemistry; Consumer Goods industry; Property and Real Estate; Transportation and Infrastructure; Finance; and Trade, Services and Investment while the Mining Sector Index does not react to CBM.
\end{abstract}

Keywords: abnormal return, china's black monday, event study 
Gde Agung Satria, Luh Gede Sri Hartini, dan Henny Rahyuda. Reaksi Pasar Terhadap....

\section{PENDAHULUAN}

Investasi merupakan pengorbanan yang dilakukan dengan harapan mendapat keuntungan di masa depan.Investasi memiliki keterkaitan yang erat dengan konsumsi karena penundaan konsumsi sekarang dapat diartikan sebagai investasi dimasa mendatang (Jogiyanto, 2010: 2). Tujuan dilakukannya konsumsi adalah untuk mendapatkan kepuasan dengan memanfaatkan sumber daya. Jika beberapa unit konsumsi dipindahkan ke investasi diharapkan kepuasan yang diterima adalah sebesar konsumsi yang dikorbankan untuk beberapa waktu. Dibutuhkan aktiva produktif yang dapat mengubah satu unit konsumsi yang dikorbankan menjadi lebih dari satu unit konsumsi di masa yang akan datang.

Pasar modal adalah salah satu tempat bagi investor untuk berinvestasi pada aktiva keuangan. Produk yang diperjualbelikan di pasar modal adalah saham, derivatif, dan surat utang. Saham adalah aktiva keuangan yang paling sering diperjualbelikan di Pasar Modal. Di Indonesia, Bursa Efek Indonesia (BEI) merupakan fasilitator bagi perdagangan saham perusahaan yang terdaftar di BEI dengan 534 perusahaan yang tercatat pada Juli 2016 (IDX, 2016). Naik turunnya harga instrumen keuangan dipengaruhi banyak faktor, salah satunya adalah kondisi perekonomian global.

Kondisi ekonomi global memiliki dampak terhadap pasar modal di berbagai negara. Dampak ini disebabkan karena kondisi ekonomi global dapat mempengaruhi prospek ekspor perusahaan, kompetisi harga dengan pesaing, atau laba yang didapat dari investasi luar negeri (Bodie et al.,2014: 237). Prospek ekspor, harga, dan laba sangat berpengaruh terhadap nilai perusahaan sehingga 
harga saham perusahaan akan mengalami perubahan apabila variabel tersebut dipengaruhi oleh suatu peristiwa global. Perubahan ini terjadi terutama ketika ada major economic event (Huyghebaert et al., 2010). Peristiwa China'sblack monday yang terjadi di tahun 2015 merupakan peristiwa global yang termasuk major economic event.

China saat ini menghadapi perlambatan pertumbuhan ekonomi (Walker, 2015). Berdasarkan data yang diririlis World Bank (2016), trend pertumbuhan PDB China mengalami penurunan sejak peristiwa Subprime Mortgage di Amerika pada tahun 2008. Data yang dirilis World Bankmenunjukkan sejak tahun 2005 pertumbuhan Produk Domestik Bruto (PDB) China selalu mengalami peningkatan tiap tahunnnya. Tahun 2005 China mencatat pertumbuhan PDB sebesar 11,4\%. Pada Tahun 2006 dan 2007 pertumbuhan PDB China meningkat dengan persentase $12,7 \%$ pada tahun 2006 , dan $14,2 \%$ pada tahun 2007 , tetapi pada tahun 2008 terjadi penurunan pertumbuhan PDB hingga dibawah $10 \%$ menjadi sebesar 9,6\%. Grafiknya dapat dilihat pada Gambar 1. berikut :

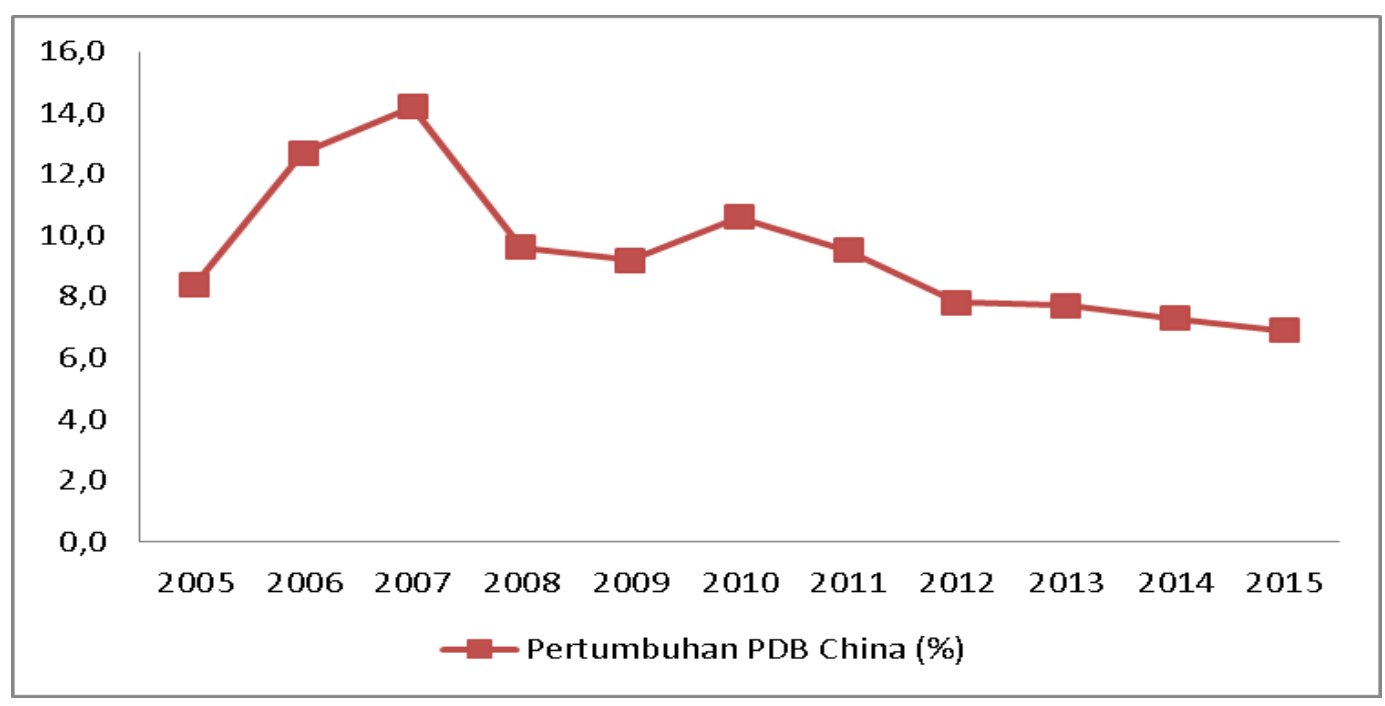

Gambar 1. Grafik Pertumbuhan Produk Domestik Bruto China Tahun 2005-2015 Sumber : World Bank, 2016 
Gde Agung Satria, Luh Gede Sri Hartini, dan Henny Rahyuda. Reaksi Pasar Terhadap....

Kejadian penurunan ini bertepatan dengan peristiwa krisis Subprime Mortgage yang melanda Amerika Serikat pada tahun 2008 yang mengakibatkan kepanikan pasar modal dunia. Penurunan pertumbuhan berlanjut di tahun 2009 menjadi 9,2\%. Tahun 2010 pertumbuhan PDB mengalami kenaikan menjadi 10,6\%. Setelah tahun 2010 pertumbuhan PDB China mengalami tren penurunan hingga tahun 2015. Tahun 2011 persentase pertumbuhan PDB China hanya sebesar 9,5\%, tahun 2012 sebesar 7,8\%, tahun 2013 sebesar 7,7\%, tahun 2014 7,3\%, dan tahun 2015 6,9\%. Fenomena ini menunjukkan bahwa China mengalami perlambatan ekonomi.

Perlambatan ekonomi China telah mengakibatkan kekhawatiran global akan kesehatan perekonomian China. Puncaknya adalah ketika jatuhnya harga saham di Bursa China dan mengakibatkan penurunan harga saham di pasar global. On Monday August $24^{\text {th }}$ China's Xinhua TV announced “Black Monday" on Twitter (Coppola, 2015). Pada hari Senin 24 Agustus 2015 telah terjadi penurunan harga saham terparah di Bursa ShanghaiChinasebesar 8,5\%, dimana telah terjadi aksi jual besar-besaran. Penurunan saham terparah ini terakhir terjadi pada tahun 2007 (Bloomberg, 2015). Beberapa media online internasional seperti Time (2015), Fortune (2015), Independent(2015), dan BBC (2015) menyebut ini sebagai peristiwa “Black Monday”.

Peristiwa China'sblack monday menyebabkan pasar global bereaksi. Di Eropa, Indeks FTSE 100 London turun 2,6\% pada perdagangan Senin pagi, sementara pasar-pasar utama di Prancis dan Jerman kehilangan hampir 3\% (BBC, 2015). Di Amerika, Indeks Dow Jones sempat turun sampai 1.000 poin sebelum 
pulih kembali pada 15.871,35 atau turun 3,6\%. Sementara itu S\&P 500 ditutup dengan penurunan 3,9\% di level 1.893,21 dan Nasdaq turun 3,8\% dengan penutupan pada 4.038,6 (BBC, 2015). Di Asia, Bursa Nikkei di Jepang mengalami penurunan 3\% ke 17.970,32. Di Korea Selatan, Indeks Kospi turun 0,5\% ke 1.821,49 sementara di Australia, indeks S\&P ASX/200 turun 0,8\% ke 5.001,90 (BBC, 2015). Di Indonesia, IHSG turun 3,97\% ke 4163,73.

Trend IHSG selama periode peristiwa China'sBlack Monday adalah sebagai berikut: Pada tanggal 24 Agustus 2015 IHSG ditutup melemah 3,97\% akibat pelemahan di China penurunan ini merupakan penurunan IHSG tertajam yang terakhir terjadi pada Agustus 2013. Pada tanggal 25 Agustus 2015 IHSG mengalami kenaikan 1,56\% ke level 4.228,50. Sejumlah bursa Asia masih tertekan menjadi sentimen negatif yang berlawanan dengan reaksi atas rencana buyback saham emiten BUMN dan emiten lainnya. Pada tanggal 26 Agustus 2015 Indeks menguat naik 0,22\% ke level 4.237,73. Pada tanggal 27 Agustus 2015 IHSG mengalami kenaikan 4,55\% ke level 4.430,63. Pada tanggal 28 Agustus IHSG menguat 0,35\% ke level 4.446,20. Menurut Coppola (2015), peristiwa China'sBlack Monday mirip seperti peristiwa Black Monday di Amerika Serikat pada tanggal 28 Oktober 1929. Pada saat itu pasar jatuh hampir mencapai $13 \%$ dimana sebelumnya telah terjadi beberapa kali penurunan saham yang tajam. Pada tahun 1929 pertumbuhan ekonomi Amerika sangat cepat akibat berkembangnya banyak industri, mirip dengan China. Pertumbuhan industri di negara China tumbuh dengan cepat. mendorong masyarakat keluar dari sektor pertanian dan perkebunan (agriculture)menuju manufaktur. 
Gde Agung Satria, Luh Gede Sri Hartini, dan Henny Rahyuda. Reaksi Pasar Terhadap....

Pesatnya pertumbuhan China bukan berasal dari utang luar negeri namun berasal dari ekspansi besar-besaran ekspor yang menyebabkan surplus neraca perdagangan dan menjadikan China sebagai kreditur global (Coppola, 2015) Tingginya utang di dalam China, baik itu utang perusahaan maupun utang pemerintah menyebabkan pertumbuhan China melambat, utang menjadi buruk, dan adanya ketidakpastian yang meningkat. Kehilangan kendali dari sistem keuangan domestik menyebabkan ketidakstabilan dan jatuhnya suplai uang. Kondisi pasar yang tidak stabil membuat pelaku pasar panik dan melakukan aksi jual untuk melindungi aset mereka yang menyebabkan jatuhnya harga saham di China.

Dampak jatuhnya saham di China terasa di Indonesia karena China dan Indonesia memiliki hubungan kerjasama ekonomi. Sejarah hubungan kerjasama Indonesia dan China telah berlangsung sejak tahun 2002. Kerjasama ini ditunjukkan dari kesepakatan kerjasama ACFTA atau ASEAN - China Free Trade Area yang dilakukan Indonesia bersama negara ASEAN lainnya pada tahun 2002 hingga sekarang. Kerjasama ini berawal dari adanya perencanaan dalam kesatuan bidang ekonomi ASEAN, yaitu integrasi ekonomi yang diharapkan tercapai pada tahun 2015, salah satunya diwujudkan melalui penerapan kegiatan perdagangan bebas atau free trade oleh ASEAN (Siwi, 2013). Seiring berkembangnya waktu perdagangan bebas ini tidak hanya dilakukan sebatas dengan negara-negara ASEAN saja, tetapi juga dengan negara di luar ASEAN. China telah menjadi sorotan utama ASEAN dalam perdagangan bebas, sehingga dibentuk kesepakatan baru yang disebut ACFTA atau ASEAN - China Free 
Trade Area (Siwi,2013). Kesepakatan kerjasama Indonesia dan China melalui ACFTA menyebabkan nilai ekspor dan impor Indonesia dengan China mendominasi Neraca Perdagangan Indonesia. Nilai ekspor ke China menempati posisi kedua dengan nilai ekspor US\$17.605,9 juta pada tahun 2014 (BPS, 2016). Sedangkan untuk nilai impor, China menempati urutan pertama dengan nilai impor US\$30 624,3 juta pada tahun 2014 (BPS, 2016).

Ekspor Indonesia ke China didominasi ekspor barang komoditas sehingga sektor pertambangan dan perdagangan memiliki peran besar terhadap ekspor ke China.Badan Pusat Statistik (BPS) dalam Viva (2011) memperkirakan bahan tambang dan minyak sawit mentah atau crude palm oil (CPO) masih akan mendominasi ekspor Indonesia ke China. Besarnya kebutuhanChinaterhadap bahan tambang dan CPO mengakibatkan impor yang dilakukan China untuk kedua komoditas itu tinggi. Perusahaan yang kegiatan bisnisnya terletak pada kedua komoditas tersebut akan terkena imbas jika impor yang dilakukan China mengalami penurunan akibat perlambatan ekonomi

Setiawan (2012) melakukan simulasi dengan membandingkan kondisi ketika skema tarif ACFTA diberlakukan dengan kondisi ketika skema tarif ACFTA tidak diberlakukan. Simulasi dilakukan selama periode 1 Januari 2009 31 Desember 2011, hasilnya ACFTA berpengaruh pada peningkatan kontribusi ekspor bagi pendapatan nasional dan persentase pertumbuhannya (Setiawan, 2012). Gejolak ekonomi di China dapat menyebabkan penurunan ekspor Indonesia ke China akibat dari turunnya permintaan barang dan jasa dari China. 
Gde Agung Satria, Luh Gede Sri Hartini, dan Henny Rahyuda. Reaksi Pasar Terhadap....

Penurunan ekspor berpengaruh pada turunnya pendapatan perusahaan di Indonesia yang mengakibatkan harga saham turun.

Pengaruh peristiwa global sepertiChina'sblack monday terhadap pasar modal dicerminkan oleh reaksi pasar yang terjadi pada pasar modal tersebut. Reaksi pasar modal terjadi akibat informasi yang masuk ke pasar yang akhirnya direspon oleh investor. Informasi ini dapat dijelaskan melalui Teori Sinyal atau Signaling Theory. Signaling Theory menyatakan bahwa setiap event atau corporate action terkait dengan sebuah perusahaan memiliki potensi muatan informasi sebagai suatu sinyal (Fahmi, 2013: 31). Peristiwa China 'sblack monday memberikan sinyal kepada dunia bahwa ini merupakan akhir dari siklus pertumbuhan China yang sangat cepat (Coppola, 2015).

Informasi ini menyebabkan reaksi yang dapat dijelaskan oleh teori pasar modal efisien. Jika pasar bereaksi dengan cepat dan akurat untuk mencapai harga keseimbangan baru yang sepenuhnya mencerminkan informasi yang tersedia, maka kondisi pasar seperti ini disebut dengan pasar efisien (Jogiyanto, 2010: 517). Event study diperlukan untuk mempelajari reaksi pasar terhadap suatu informasi. Studi Peristiwa (event study) merupakan studi yang mempelajari reaksi pasar terhadap suatu peristiwa (event) yang informasinya dipublikasikan sebagai suatu pengumuman (Jogiyanto, 2010: 555).Event study dapat digunakandalam menguji adanya kandungan informasi dari sebuah pengumuman dan juga untuk menguji efisiensi pasar dalam bentuk setengah kuat.

Efisiensi pasar dapat diuji dengan melihat return tak wajar atau abnormalreturn(Jogiyanto, 2010: 556). Abnormalreturn adalah selisih dari 
returnyang diekspektasikan dengan returnyang terealisasi. Pengujian adanya abnormalreturntidak dilakukan untuk tiap-tiap sekuritas, tetapi dilakukan secara agregat dengan menguji rata-rata abnormalreturnseluruh sekuritas secara crosssection untuk tiap-tiap hari di periode peristiwa (Jogiyanto, 2010: 592). Pengujian statistik dilakukan untuk melihat signifikansi dari abnormalreturn. Signifkansi yang dimaksud adalah bahwa abnormalreturn tersebut secara statistik signifikan tidak sama dengan nol (Jogiyanto, 2010: 598).

Penelitian yang dilakukan oleh Mahmood et al (2011), Kumar dan Liu (2013), Ferstl et al (2012), Goodell dan Bodey (2012), Joshipura (2013), Bekaert et al., (2011),Ahmad et al., (2014), Khajar (2015), Ranjeeni dan Sharma (2015), Gumanti dan Palupi (2008), Aini dan Djumahir (2016), Prasojo (2012), Jain et al., (2013), Luchtenberg dan Seiler (2014),Afif et al.,(2015), Arisyi et al., (2012), Nezky (2013), Trihadmini (2011), menunjukkan bahwa peristiwa global dapat menyebabkan pasar modal bereaksi sedangkan penelitian yang dilakukan oleh Ramiah (2012), Zainuddin (2016),dan Angelovska (2011) menunjukkan bahwa peristiwa global tidak menyebabkan pasar modal bereaksi. China sblack Monday adalah peristiwa global yang dampaknya dirasakan di seluruh dunia termasuk di Indonesia. Sebagai negara yang terintegrasi dengan ekonomi global, Indonesia sulit untuk menghindari dampak dari peristiwa global tersebut. Hal ini disebabkan karena peristiwa China's Black Mondaymemiliki kandungan informasi, sehingga pasar bereaksi atas peristiwa ini. Penelitian yang dilakukan untuk menguji dampak peristiwa global terhadap pasar modal menunjukkan hasil yang beragam. Hal ini menunjukkan tidak semua peristiwa global berdampak pada pasar modal. 
Gde Agung Satria, Luh Gede Sri Hartini, dan Henny Rahyuda. Reaksi Pasar Terhadap....

Berdasarkan latar belakang, adapun rumusan masalah penelitian ini yaitu apakah terdapat reaksi pasar akibatperistiwa China'sblack Monday pada masingmasing indeks sektoral di Bursa Efek Indonesia? Tujuan dari penelitian ini adalah untuk menguji reaksi pasar akibatperistiwa China'sblack Monday pada masingmasing indeks sektoral di Bursa Efek Indonesia.Penelitian sebelumnya yang dilakukan oleh Mahmood et al (2011), Kumar dan Liu (2013), Ferstl et al (2012), Goodell dan Bodey (2012), Joshipura (2013), Ahmad et al (2014), Khajar (2015), Ranjeeni dan Sharma (2015), Gumanti dan Palupi (2008), Aini dan Djumahir (2016), Prasojo (2012), menunjukkan bahwa peristiwa global dapat menyebabkan pasar modal bereaksi. sehingga dapat dirumuskan hipotesis dalam penelitian ini adalah sebagai berikut:

H1: Terdapat reaksi pasar yang signifikan pada masing-masing Indeks Sektoral selama periode peristiwa akibat China's Black Monday

Penelitian ini diharapkan dapat memberikan bukti empiris mengenai reaksi pasar terhadap peristiwa China'sblack Monday khususnya pada indeks sektoral. Penelitian ini juga diharapkan dapat dijadikan pertimbangan bagi pelaku pasar modal dalam mengambil keputusan terkait investasi yang dilakukan di Bursa Efek Indonesia apabila terjadi peristiwa global seperti China'sblack Monday dan menambah informasi investor sehingga meminimalkan risiko yang akan ditanggung nantinya. 


\section{METODE PENELITIAN}

Penelitian ini menggunakan pendekatan kuantitatif dengan jenis penelitian berbentuk event study. Penelitian event study yaitu penelitian yang mengukur reaksi pasar modal akibat informasi atau pengumuman yang masuk ke pasar. Pasar modal yang bereaksi dicerminkan oleh adanya abnormalreturn akibat informasi yang masuk ke pasar. Apabila tidak terdapat abnormalreturn maka tidak terdapat kandungan informasi dari suatu pengumuman.

Model yang digunakan untuk mengestimasi return ekspektasian adalah Market Adjusted Model. Model sesuaian pasar atau Market Adjusted Model menggunakan IHSG sebagai dasar untuk mengukur abnormalreturn. Model ini menganggap return indeks pasar pada hari pengumuman adalah return yang diharapkan pada suatu sekuritas. Alasan menggunakan Market Adjusted Model adalah menurut Brown and Warner (1985) dalamRanjeeni and Sharma (2015) menemukan bahwa pada studi peristiwa yang menggunakan data harian, model ini memiliki kinerja yang baik dan powerful digunakan pada waktu peristiwa (event date) yang dikelompokkan. Model ini juga digunakan pada kondisi dimana tidak fisibel untuk mendapatkan periode estimasi sebelum kejadian yang digunakan pada parameter model normal (MacKinlay, 1997). Penelitian ini menguji reaksi pasar modal akibat peristiwa China's Black Monday yang terjadi pada 24 Agustus 2015. Indeks yang diteliti adalah indeks sektoral. Alasan memilih indeks sektoral adalah agar dapat diketahui sektor mana yang terkena dampak pada peristiwa China's Black Monday. Data penelitian ini akan diolah dan dianalisis serta didukung dengan teori pustaka agar dapat membuktikan hipotesis serta menjawab 
Gde Agung Satria, Luh Gede Sri Hartini, dan Henny Rahyuda. Reaksi Pasar Terhadap....

rumusan masalah yang telah ditetapkan sebelumnya. Data yang digunakan dalam penelitian ini adalah data sekunder yang terdiri dari data harga saham perusahaan di semua sektor. Data ini diperoleh dari Bursa Efek Indonesia (BEI) melalui situs www.idx.co.id

Variabel yang dianalisis adalah abnormalreturn.Penelitian ini menggunakan jendela peristiwa 5 hari yaitu 1 hari saat peristiwa, dan 4 hari sesudah China'sblack Monday. Tanggal pengamatan dimulai pada 24 Agustus 2015 sampai 28 Agustus 2015 dengan menggunakan harga saham penutupan pada seluruh perusahaan yang terdaftar di Bursa Efek Indonesia yang terbagi dalam 9 sektor. Jenis data yang digunakan adalah jenis data kualitatif dan kuantitatif.Data kualitatif dalam penelitian ini adalah artikel-artikel berita dan dari Bursa Efek Indonesia, sedangkan untuk data kuantitatif berupa data harga saham penutupan selama periode peristiwa. Berdasarkan sumbernya, data yang digunakan dalam penelitian ini adalah data sekunder yaitu data yang diperoleh dalam bentuk sudah jadi sudah dikumpulkan dan diolah oleh pihak lain. Data penelitian ini diperoleh dari data publikasi harga saham yang terdapat pada website resmi Bursa Efek Indonesia (www.idx.co.id).

Populasi dari penelitian ini adalah seluruh perusahaan yang tidak melakukan corporate action pada periode peristiwa di Bursa Efek Indonesia dan dibagi menjadi 9 sektor.Pengumpulan data menggunakan metode sensus.Di Bursa Efek Indonesia saat ini terdapat 532 perusahaan yang dibagi menjadi 9 sektor yang dapat dilihat pada tabel 1.: 
Tabel 1.

Jumlah Perusahaan Pada Indeks Sektoral

\begin{tabular}{clc}
\hline No & \multicolumn{1}{c}{ Indeks Sektoral } & Jumlah Perusahaan \\
\hline 1 & Pertanian & 21 \\
2 & Pertambangan & 43 \\
3 & Industri Dasar dan Kimia & 66 \\
4 & Aneka Industri & 40 \\
5 & Industri Barang Konsumsi & 38 \\
6 & Properti dan Real Estate & 61 \\
7 & Transportasi dan Infrastruktur & 56 \\
8 & Keuangan & 88 \\
9 & Perdagangan Jasa dan Investasi & 119 \\
\hline \multicolumn{2}{l}{ Sumber: Data diolah , 2016 }
\end{tabular}

Metode analisis data yang digunakan untuk menguji adanya reaksi pasar adalah dengan menggunakan Uji-t. Pengujian dilakukan dengan menghitung abnormalreturnpada periode peristiwa di masing-masing perusahaan pada 9 sektor. Mencari return ekspektasi dengan market adjusted model tidak perlu membentuk model estimasi terlebih dahulu, hal ini disebabkan imbal hasil yang disetimasi dianggap sama dengan imbal hasil indeks pasar. Jadi, abnormalreturndihitung dengan cara mengurangi return sekuritas pada periode peristiwa dengan return IHSG pada periode peristiwa yang sama.

\section{HASIL DAN PEMBAHASAN}

Uji statistik deskriptif dilakukan untuk memberikan gambaran atau deskripsi mengenai variabel yang diteliti yaitu abnormal return.Hasil analisis deskriptif dapat dilihat pada tabel 2 dan tabel 3. 
Tabel 2.

Hasil Analisis Deskriptif Abnormal Return Indeks Sektoral di Bursa Efek Indonesia (minimum dan maximum)

\begin{tabular}{|c|c|c|c|c|c|c|c|c|c|c|c|c|}
\hline \multirow{2}{*}{ No } & \multirow{2}{*}{ Sektor } & \multirow{2}{*}{$\mathrm{N}$} & \multicolumn{5}{|c|}{ Minimum } & \multicolumn{5}{|c|}{ Maximum } \\
\hline & & & t0 & $\mathrm{t} 1$ & $\mathrm{t} 2$ & $\mathrm{t} 3$ & $\mathrm{t} 4$ & to & $\mathrm{t} 1$ & $\mathrm{t} 2$ & $\mathrm{t} 3$ & $\mathrm{t} 4$ \\
\hline 1 & Pertanian & 21 & $-0,17$ & $-0,11$ & $-0,10$ & $-0,14$ & $-0,06$ & 0,06 & 0,10 & 0,34 & 0,14 & 0,09 \\
\hline 2 & Pertambangan & 43 & $-0,09$ & $-0,12$ & $-0,10$ & $-0,09$ & $-0,08$ & 0,05 & 0,13 & 0,05 & 0,08 & 0,09 \\
\hline 3 & $\begin{array}{l}\text { Industri Dasar } \\
\text { dan Kimia }\end{array}$ & 66 & $-0,21$ & $-0,11$ & $-0,08$ & $-0,14$ & $-0,07$ & 0,29 & 0,22 & 0,18 & 0,28 & 0,22 \\
\hline 4 & $\begin{array}{l}\text { Aneka Industri } \\
\text { Industri } \\
\text { Barang }\end{array}$ & 40 & $-0,10$ & $-0,11$ & $-0,10$ & $-0,14$ & $-0,08$ & 0,05 & 0,04 & 0,10 & 0,08 & 0,06 \\
\hline 5 & $\begin{array}{l}\text { Konsumsi } \\
\text { Properti dan }\end{array}$ & 38 & $-0,10$ & $-0,07$ & $-0,04$ & $-0,10$ & $-0,10$ & 0,06 & 0,08 & 0,04 & 0,05 & 0,17 \\
\hline 6 & $\begin{array}{l}\text { Real Estate } \\
\text { Transportasi } \\
\text { dan }\end{array}$ & 61 & $-0,10$ & $-0,12$ & $-0,09$ & $-0,14$ & $-0,10$ & 0,10 & 0,04 & 0,08 & 0,09 & 0,06 \\
\hline 7 & Infrastruktur & 56 & $-0,1$ & $-0,1$ & $-0,1$ & $-0,1$ & $-0,1$ & 0,07 & 0,15 & 0,13 & 0,14 & 0,1 \\
\hline 8 & $\begin{array}{l}\text { Keuangan } \\
\text { Perdagangan, } \\
\text { Jasa dan }\end{array}$ & 88 & $-0,20$ & $-0,12$ & $-0,10$ & $-0,14$ & $-0,03$ & 0,13 & 0,17 & 0,08 & 0,06 & 0,07 \\
\hline 9 & Investasi & 119 & $-0,17$ & $-0,12$ & $-0,10$ & $-0,14$ & $-0,10$ & 0,14 & 0,12 & 0,26 & 0,15 & 0,17 \\
\hline
\end{tabular}

Sektor Pertanian dengan jumlah populasi yang diteliti sebesar 21 perusahaan, memiliki nilai abnormal return terkecil selama periode peristiwa ( $\mathrm{t} 0$ t4) berurutan dengan nilai- $-0,17 ;-0,11 ;-0,10 ;-0,14 ;-0,06$; sedangkan nilai abnormal return terbesar selama periode peristiwa ( $\mathrm{t} 0$ - $\mathrm{t} 4)$ berturut-turut adalah sebesar 0,$06 ; 0,10 ; 0,34 ; 0,14 ; 0,09$. Pada Sektor Pertambangan dengan jumlah populasi yang diteliti sebesar 43 perusahaan, memiliki nilai abnormal return terkecil selama periode peristiwa (t0 - t4) berurutan dengan nilai-0,09; -0,12; 0,$10 ;-0,09 ;-0,08$; sedangkan nilai abnormal return terbesar selama periode peristiwa (t0 - t4) berturut-turut adalah sebesar 0,05; 0,13;0,05; 0,08; $0,09$. 
Sektor Industri Dasar dan Kimia dengan jumlah populasi yang diteliti sebesar 66 perusahaan, memiliki nilai abnormal return terkecil selama periode peristiwa (t0 - t4) berurutan dengan nilai-0,21;-0,11-0,08; -0,14;0,07; sedangkan nilai abnormal return terbesar selama periode peristiwa $(\mathrm{t} 0$ - $\mathrm{t} 4)$ berturut-turut adalah sebesar 0,29;0,22;0,18;0,28;0,22. Pada Sektor Aneka Industri dengan jumlah populasi yang diteliti sebesar 40 perusahaan, memiliki nilai abnormal return terkecil selama periode peristiwa (t0 - t4) berurutan dengan nilai -0,10; 0,$11 ;-0,10 ;-0,14 ;-0,08$; sedangkan nilai abnormal return terbesar selama periode peristiwa (t0 - t4) berturut-turut adalah sebesar 0,$05 ; 0,04 ; 0,10 ; 0,08 ; 0,06$.

Sektor Industri Dasar dan Kimia dengan jumlah populasi yang diteliti sebesar 66 perusahaan, memiliki nilai abnormal return terkecil selama periode peristiwa (t0 - t4) berurutan dengan nilai-0,21; - -0,11; - -0,08; - -0,14; -0,07; sedangkan nilai abnormal return terbesar selama periode peristiwa (t0 - t4) berturut-turut adalah sebesar 0,$29 ; 0,22 ; 0,18 ; 0,28 ; 0,22$. Pada Sektor Aneka Industri dengan jumlah populasi yang diteliti sebesar 40 perusahaan, memiliki nilai abnormal return terkecil selama periode peristiwa $(\mathrm{t} 0$ - $\mathrm{t} 4)$ berurutan dengan nilai $-0,10 ;-0,11 ;-0,10 ;-0,14 ;-0,08$; sedangkan nilai abnormal return terbesar selama periode peristiwa (t0 - t4) berturut-turut adalah sebesar 0,$05 ; 0,04 ; 0,10$; 0,$08 ; 0,06$.

Sektor Industri Barang Konsumsi dengan jumlah populasi yang diteliti sebesar 38 perusahaan, memiliki nilai abnormal return terkecil selama periode peristiwa (t0 - t4) berurutan dengan nilai-0,10; - -0,07; - -0,04; - -0,10; -0,10; sedangkan nilai abnormal return terbesar selama periode peristiwa (t0 - t4) 
Gde Agung Satria, Luh Gede Sri Hartini, dan Henny Rahyuda. Reaksi Pasar Terhadap....

berturut-turut adalah sebesar 0,06; 0,08; 0,04; 0,05; 0,17. Pada Sektor Properti dan Real Estate dengan jumlah populasi yang diteliti sebesar 61 perusahaan, memiliki nilai abnormal return terkecil selama periode peristiwa $(\mathrm{t} 0$ - $\mathrm{t} 4)$ berurutan dengan nilai- 0,$10 ;-0,12 ;-0,09 ;-0,14 ;-0,10$; sedangkan nilai abnormal return terbesar selama periode peristiwa $(\mathrm{t} 0$ - $\mathrm{t} 4)$ berturut-turut adalah sebesar 0,$10 ; 0,04 ; 0,08$; 0,$09 ; 0,06$.

Sektor Transportasi dan Infrastruktur dengan jumlah populasi yang diteliti sebesar 56 perusahaan, memiliki nilai abnormal return terkecil selama periode peristiwa (t0 - t4) berurutan dengan nilai- 0,$11 ;-0,12 ;-0,10 ;-0,14 ;-0,10$; sedangkan nilai abnormal return terbesar selama periode peristiwa (t0 - t4) berturut-turut adalah sebesar 0,$07 ; 0,15 ; 0,13 ; 0,14 ; 0,10$. Pada Sektor Keuangan dengan jumlah populasi yang diteliti sebesar 88 perusahaan, memiliki nilai abnormal return terkecil selama periode peristiwa ( $\mathrm{t} 0$ - $\mathrm{t} 4)$ berurutan dengan nilai0,$20 ;-0,12 ;-0,10 ;-0,14 ;-0,03$; sedangkan nilai abnormal return terbesar selama periode peristiwa (t0 - t4) berturut-turut adalah sebesar 0,$13 ; 0,17 ; 0,08 ; 0,06$; 0,07 .

Sektor Perdagangan, Jasa dan Investasidengan jumlah populasi yang diteliti sebesar 119 perusahaan, memiliki nilai abnormal return terkecil selama periode peristiwa (t0 - t4) berurutan dengan nilai $-0,17 ;-0,12 ;-0,10 ;-0,14 ;-0,10$; sedangkan nilai abnormal return terbesar selama periode peristiwa ( $\mathrm{t} 0$ - $\mathrm{t} 4$ ) berturut-turut adalah sebesar 0,$14 ; 0,12 ; 0,26 ; 0,15 ; 0,17$. 
ISSN : 2337-3067

E-Jurnal Ekonomi dan Bisnis Universitas Udayana 6.7 (2017): 2635-2664

Tabel 3.

Hasil Analisis Deskriptif Abnormal Return Indeks Sektoral di Bursa Efek Indonesia (mean dan std. deviation)

\begin{tabular}{|c|c|c|c|c|c|c|c|c|c|c|c|}
\hline \multirow{2}{*}{ No } & \multirow{2}{*}{ Sektor } & \multicolumn{5}{|c|}{ Mean } & \multicolumn{5}{|c|}{ Std. Deviation } \\
\hline & & t0 & $\mathrm{t} 1$ & $\mathrm{t} 2$ & $\mathrm{t} 3$ & $\mathrm{t} 4$ & t0 & $\mathrm{t} 1$ & $\mathrm{t} 2$ & $\mathrm{t} 3$ & $\mathrm{t} 4$ \\
\hline 1 & Pertanian & $-0,02$ & $-0,02$ & 0,01 & $-0,02$ & 0,01 & 0,06 & 0,05 & 0,09 & 0,07 & 0,04 \\
\hline 2 & Pertambangan & 0,00 & $-0,01$ & 0,00 & $-0,03$ & 0,00 & 0,04 & 0,04 & 0,03 & 0,04 & 0,03 \\
\hline 3 & $\begin{array}{l}\text { Industri Dasar } \\
\text { dan Kimia }\end{array}$ & 0,01 & $-0,01$ & 0,00 & $-0,03$ & 0,01 & 0,07 & 0,04 & 0,04 & 0,06 & 0,05 \\
\hline 4 & $\begin{array}{l}\text { Aneka Industri } \\
\text { Industri }\end{array}$ & 0,01 & $-0,03$ & $-0,01$ & $-0,03$ & 0,00 & 0,04 & 0,04 & 0,03 & 0,04 & 0,03 \\
\hline 5 & $\begin{array}{l}\text { Barang } \\
\text { Konsumsi }\end{array}$ & 0,01 & $-0,02$ & 0,00 & $-0,03$ & 0,00 & 0,04 & 0,03 & 0,01 & 0,03 & 0,04 \\
\hline 6 & $\begin{array}{l}\text { Properti dan } \\
\text { Real Estate } \\
\text { Transportasi } \\
\text { dan }\end{array}$ & 0,00 & $-0,02$ & $-0,01$ & $-0,02$ & $-0,01$ & 0,05 & 0,03 & 0,03 & 0,04 & 0,03 \\
\hline 7 & Infrastruktur & 0,01 & $-0,02$ & $-0,01$ & $-0,03$ & 0,00 & 0,04 & 0,04 & 0,03 & 0,04 & 0,04 \\
\hline 8 & $\begin{array}{l}\text { Keuangan } \\
\text { Perdagangan, } \\
\text { Jasa dan } \\
\text { Investasi }\end{array}$ & 0,02 & $-0,01$ & 0,00 & $-0,03$ & 0,00 & 0,04 & 0,04 & 0,03 & 0,04 & 0,02 \\
\hline
\end{tabular}

Rata-rata abnormal return Sektor Pertanian selama periode peristiwa (t0 t4) berturut-turut adalah sebesar $-0,02 ;-0,02 ; 0,01 ;-0,02 ; 0,01$; dengan nilai simpangan baku selama eriode peristiwa (t0 - t4) berturut-turut adalah sebesar 0,06; 0,05; 0,09; 0,07; 0,04. Pada Sektor Pertambangan, rata-rata abnormal return 
Gde Agung Satria, Luh Gede Sri Hartini, dan Henny Rahyuda. Reaksi Pasar Terhadap....

selama periode peristiwa $(\mathrm{t} 0$ - $\mathrm{t} 4)$ berturut-turut adalah sebesar 0,$00 ;-0,01 ; 0,00 ;-$ 0,03; 0,00; dengan nilai simpangan baku selama periode peristiwa (t0 - t4) berturut-turut adalah sebesar 0,04;0,04;0,03;0,04; 0,03. Pada Sektor Industri Dasar dan Kimia, rata-rata abnormal return selama periode peristiwa ( $\mathrm{t} 0$ - $\mathrm{t} 4$ ) berturut-turut adalah sebesar 0,$01 ;-0,01 ; 0,00 ;-0,03 ; 0,01 ;$ dengan nilai simpangan baku selama periode peristiwa (t0 - t4) berturut-turut adalah sebesar 0,$07 ; 0,04 ; 0,04 ; 0,06 ; 0,05$.

Rata-rata abnormal return Sektor Aneka Industri selama periode peristiwa $(\mathrm{t} 0-\mathrm{t} 4)$ berturut-turut adalah sebesar 0,$01 ;-0,03 ;-0,01 ;-0,03 ; 0,00 ;$ dengan nilai simpangan baku selama periode peristiwa ( $\mathrm{t} 0$ - $\mathrm{t} 4)$ berturut-turut adalah sebesar 0,04; 0,04;0,03;0,04; 0,03. Pada Sektor Industri Barang Konsumsi, rata-rata abnormal return selama periode peristiwa (t0 - t4) berturut-turut adalah sebesar 0,$01 ;-0,02 ; 0,00 ;-0,03 ; 0,00 ;$ dengan nilai simpangan baku selama periode peristiwa (t0 - t4) berturut-turut adalah sebesar 0,$04 ; 0,03 ; 0,01 ; 0,03 ; 0,04$. Pada Sektor Properti dan Real Estate, rata-rata abnormal return selama periode peristiwa (t0 - t4) berturut-turut adalah sebesar 0,$00 ;-0,02 ;-0,01 ;-0,02 ;-0,01$; dengan nilai simpangan baku selama periode peristiwa (t0 - t4) berturut-turut adalah sebesar 0,$05 ; 0,03 ; 0,03 ; 0,04 ; 0,03$. Rata-rata abnormal return Sektor Transportasi dan Infrastruktur selama periode peristiwa (t0 - t4) berturut-turut adalah sebesar 0,$01 ;-0,02 ;-0,01 ;-0,03 ; 0,00$; dengan nilai simpangan baku selama periode peristiwa ( $\mathrm{t} 0$ - $\mathrm{t} 4)$ berturut-turut adalah sebesar 0,$04 ; 0,04 ; 0,03$; 0,04; 0,04. Pada Sektor Keuangan, rata-rata abnormal return selama periode peristiwa (t0 - t4) berturut-turut adalah sebesar 0,$02 ;-0,01 ; 0,00 ;-0,03 ; 0,00$; 
dengan nilai simpangan baku selama periode peristiwa (t0 - t4) berturut-turut adalah sebesar 0,$04 ; 0,04 ; 0,03 ; 0,04 ; 0,02$. Pada Sektor Perdagangan, Jasa dan Investasi, rata-rata abnormal return selama periode peristiwa (t0 - t4) berturutturut adalah sebesar 0,$02 ;-0,01 ; 0,00 ;-0,03 ; 0,00$; dengan nilai simpangan baku selama periode peristiwa (t0 - t4) berturut-turut adalah sebesar 0,04;0,04;0,04; 0,$04 ; 0,03$.

Pengujian hipotesis tentang reaksi pasar terhadap China's Black Mondaydi Bursa Efek Indonesiamenggunakan uji t untuk menguji signifikansi abnormal returnselama periode peristiwa dengan mengambil hipotesis 0 bahwa nilai ratarata abnormal return sama dengan nol. Pengujian dilakukan dengan cara membandingkan nilai t-hitung dengan t-tabel. Apabila t-hitung $>\mathrm{t}$ tabel atau $-\mathrm{t}$ hitung < -t tabel maka H0 dapat ditolak. Hasil pengujian dapat dilihat pada tabel 4. berikut:

\section{Tabel 4.}

Signifikansi Abnormal Return ketika Periode Peristiwa pada Indeks Sektoral

\begin{tabular}{|c|c|c|c|c|c|c|c|c|}
\hline \multirow{2}{*}{ Sektor } & \multicolumn{8}{|c|}{ Periode Peristiwa } \\
\hline & to & $\mathrm{t} 1$ & $\mathrm{t} 2$ & & $\mathrm{t} 3$ & & $\mathrm{t} 4$ & \\
\hline Pertanian & $-1,304$ & $-2,230$ & 0,402 & & $-1,580$ & & 0,678 & \\
\hline Pertambangan & 0,419 & $-1,005$ & $-0,943$ & & $-4,783$ & $*$ & 0,963 & \\
\hline Industri Dasar dan Kimia & 0,830 & $-2,676$ & $-0,012$ & & $-4,098$ & $*$ & 2,141 & $*$ \\
\hline Aneka Industri & 1,178 & $-4,829$ & $-1,436$ & & $-5,220$ & $*$ & $-0,821$ & \\
\hline Industri Barang Konsumsi & 1,777 & $-3,479$ & $-1,083$ & & $-5,036$ & $*$ & $-0,240$ & \\
\hline Properti dan Real Estate & $-0,568$ & $-5,354$ & $-2,679$ & $*$ & $-3,126$ & $*$ & $-1,925$ & \\
\hline $\begin{array}{l}\text { Transportasi dan } \\
\text { Infrastruktur }\end{array}$ & 1,447 & $-2,899$ & $-1,513$ & & $-5,521$ & $*$ & 0,973 & \\
\hline
\end{tabular}


Gde Agung Satria, Luh Gede Sri Hartini, dan Henny Rahyuda. Reaksi Pasar Terhadap....

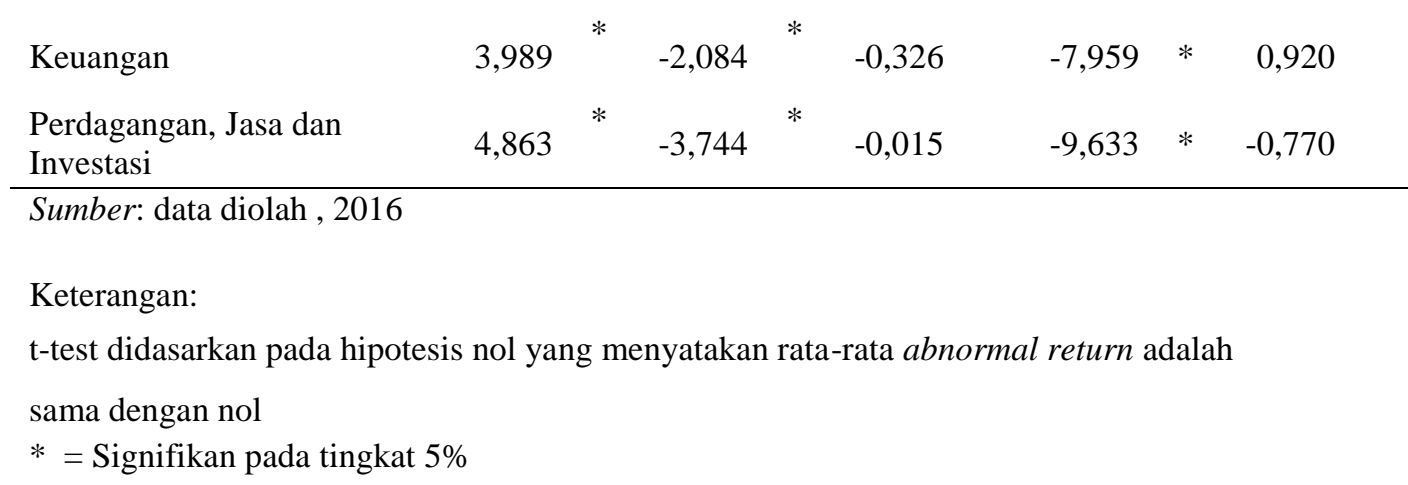

Hasil uji-t dapat diketahui dengan membandingkan nilai t-tabel dengan nilai t-hitung. Pengujian dilakukan dengan dua sisi, jadi apabila nilai t-hitung positif akan signifikan apabila t-hitung>t-tabel, tetapi jika nilai t-hitung negatif akan signifikan apabila (-t-hitung) $<(-t$-tabel). Hasil yang positif signifikan memiliki makna bahwa investor menganggap peristiwa China's Black Monday (CBM) mengandung informasi baik (good news), sedangkan hasil yang negatif signifikan memiliki makna bahwa investor menganggap peristiwa CBM mengandung informasi buruk (bad news).

Hasil uji-t menunjukkan pada Sektor Pertanian, secara statistik dengan nilai t-tabel sebesar 2,086 atau -2,086, memiliki nilai rata-rata abnormal returnpada hari t1 yang negatif signifikan karena (-t-hitung) $<$ (-t-tabel). Pada Sektor Pertambangan, secara statistik dengan nilai t-tabel sebesar 2,018 atau 2,018, terjadi rata-rata abnormal returnyang negatif signifikan pada hari t3karena (-t-hitung)<(-t-tabel). Pada Indeks Sektor Industri Dasar dan Kimia, secara statistik dengan nilai t-tabel sebesar 1,997 atau $-1,997$, nilai rata-rata abnormal return pada hari $\mathrm{t} 1$ dan $\mathrm{t} 3$ menunjukkan hasil yang negatif signifikan karena (-thitung $)<(-t$-tabel), sedangkan pada hari t4 menunjukkan hasil yang positif 
signifikan karena t-hitung>t-tabel. Pada Indeks Sektor Aneka Industri, secara statistik dengan nilai t-tabel sebesar 2,023 atau -2,023, rata-rata abnormal return pada hari t1 dan $\mathrm{t} 3$ menunjukkan hasil yang negatif signifikan karena (-thitung $)<(-$ t-tabel $)$

Pada Indeks Sektor Industri Barang Konsumsi, secara statistik dengan nilai t-tabel sebesar 2,026 atau -2,026, rata-rata abnormal return pada hari t1 dan t3negatif signifikan karena (-t-hitung) $<(-t-t a b e l)$. Pada Sektor Properti dan Real Estate, secara statistik dengan nilai t-tabel sebesar 2,000 atau $-2,000$, rata-rata abnormal return pada hari t1, t2, t3negatif signifikan karena (-t-hitung) $<$ (-ttabel).Indeks Sektor Transportasi dan Infrastruktur, secara statistik dengan nilai ttabel sebesar 2,004 atau -2,004, nilai abnormalretun pada hari t1 dan t3negatif signifikan karena (-t-hitung)<(-t-tabel). Pada Sektor Keuangan, secara statistik dengan nilai t-tabel sebesar 2,023 atau -2,023, nilai rata-rata abnormal return pada hari t0positif signifikan karena t-hitung>t-tabel, sedangkan pada hari t1 dan t3negatif signifikan karena (-t-hitung) $<(-t-t a b e l)$.

Sektor Perdagangan, Jasa dan Investasi, secara statistik dengan nilai ttabel sebesar 2,023 atau -2,023, nilai rata-rata abnormal return pada hari t0positif signifikan karena t-hitung>t-tabel, sedangkan pada hari t1 dan t3negatif signifikan karena (-t-hitung) $<(-t$-tabel).

Studi peristiwa (event study) adalah bentuk studi untuk menguji rekasi pasar dan efisiensi pasar bentuk setengah kuat (semi-strong form).Studi peristiwa dalam penelitian ini menyelidiki respon pasar terhadap kandungan informasi dari peristiwa China's Black Monday (CBM). Tujuan dari studi peristiwa ada tiga 
Gde Agung Satria, Luh Gede Sri Hartini, dan Henny Rahyuda. Reaksi Pasar Terhadap....

yaitu untuk pengujian abnormal return, pengujian respon pasar, dan pengujian teori. Pengujian abnormal return dilakukan untuk mengetahui apakah suatu peristiwa mengandung informasi. Pengujian respon pasar terkait dengan kecepatan respon pasar dan ketepatan respon pasar, sedangkan pengujian teori dilakukan dengan menguji hipotesis efisiensi pasar bentuk setengah kuat.

Pengujian abnormal return pada penelitian ini dilakukan dengan pengujian statistik menggunakan uji-t. Uji-t pada penelitian ini bertujuan untuk menguji hipotesis nol yang menyatakan rata-rata abnormal return adalah sama dengan nol, dengan membandingkan t-hitung dengan t-tabel. Dilihat dari tabel 4 hasil pengujian yang dilakukan menunjukkan bahwa terdapat abnormal return yang signifikan hampir di seluruh sektor kecuali sektor Pertambangan akibat peristiwa CBM. Adanya abnormal return yang signifikan berarti pasar bereaksi akibat peristiwa CBM. Hasil ini sejalan dengan hipotesis yang menyatakan terdapat reaksi pasar yang signifikan pada masing-masing Indeks Sektoralselama periode peristiwa akibat CBM. Sedangkan Indeks Sektor Pertambangan tidak mendukung hipotesis.

Hasil penelitian menunjukkan pada Sektor Pertanian; Aneka Industri; Industri Dasar dan Kimia; Industri Barang Konsumsi; Properti dan Real Estate; dan Transportasi dan Infrastruktur; terjadi abnormal return yang negatif signifikan pada hari t0 dan $\mathrm{t} 1$, hal ini menunjukkan bahwa terdapat reaksi pasar pada sektor tersebut akibat peristiwa CBM. Rata-rata abnormal return yang negatif memiliki makna bahwa investor menganggap peristiwa CBM akan 
berpengaruh buruk terhadap arus kas perusahaan di masa depan sehingga investor melepas sahamnya untuk melindungi nilai aset yang dimiliki.

Pada Sektor Keuangan; dan Sektor Perdagangan, Jasa dan Investasi, hasil penelitian menunjukkan terdapat rata-rata abnormal return yang positif signifikan pada hari t0, sedangkan pada hari t1, terdapat rata-rata abnormal return negatif signifikan, hal ini menunjukkan bahwa terdapat reaksi pasar pada sektor tersebut akibat peristiwa CBM. Rata-rata abnormal return yang positif memiliki arti bahwa pada hari t0 penurunan harga pada kedua sektor tersebut lebih kecil dibandingkan penurunan harga pada indeks pasar atau IHSG tetapi pada hari $\mathrm{t} 1$ sentimen investor berubah negatf yang dilihat dari rata-rata abnormal return yang negatif. Rata-rata abnormal return negatif memiliki makna bahwa investor menganggap peristiwa CBM akan berpengaruh buruk terhadap arus kas pada perusahaan-perusahaan di sektor Keuangan; dan Perdagangan, Jasa, dan Investasi di masa depan sehingga investor melepas sahamnya untuk melindungi nilai aset yang dimiliki.

Pada sektor pertambangan, tidak terjadi abnormal return yang signifikan pada hari t0 maupun t1. Tidak adanya abnormal return diduga diakibatkan banyak investor sudah lebih dulu melindungi asetnya sehingga ketika peristiwa CBM terjadi investor tidak kaget. Banyak Investor sudah melindungi asetnya sebelum CBM dikarenakan trend perlambatan ekonomi China telah terjadi sebelum peristiwa CBM. Perlambatan ekonomi China berdampak pada sektor pertambangan karena sektor pertambangan memiliki peran besar terhadap ekspor 
Gde Agung Satria, Luh Gede Sri Hartini, dan Henny Rahyuda. Reaksi Pasar Terhadap....

ke China (Viva, 2011) sehingga investor akan melindungi asetnya sebelum nilai asetnya semakin kecil akibat sentimen negatif perlambatan ekonomi China.

Abnormal return yang negatif signifikan pada hari t 2 dan $\mathrm{t} 3$ pada Sektor Pertambangan; Aneka Industri; Industri Barang Konsumsi; Properti dan Real Estate; Transportasi dan Infrastruktur; Keuangan; dan Sektor Perdagangan, Jasa dan Investasi diduga bukan disebabkan oleh CBM. Pada tanggal 25 Agustus 2015 (t2) malam, People Bank of China (PboC)yang merupakan Bank Sentral China menurunkan suku bunga pinjaman satu tahun sebesar 25 basis poin ke 4,6\% dan menurunkan giro wajib minimum sebesar 50 basis poin (Gosta, 2015). Kebijakan PboC diduga menyebabkan pasar modal bereaksi karena kebijakan PboC mengakibatkan yuan terdepresiasi. Depresiasi yuan di masa depan akan berdampak pada ekspor perusahaan ke China sehingga investor bereaksi negatif. Perusahaan sekuritas Henan Putihrai dalam Sukirno (2015) juga mengemukakan bahwa Penurunan yuan membuat potensi pertumbuhan ekspor Indonesia ke China menjadi semakin kecil

Reaksi negatif signifikan pada Sektor Pertanian; Aneka Industri; Industri Dasar dan Kimia; Industri Barang Konsumsi; Properti dan Real Estate; Transportasi dan Infrastruktur; Keuangan; dan Perdagangan „Jasa, dan Investasi ditemukan di antara hari t0 dan $\mathrm{t} 1$ mengindikasikan pasar bereaksi cepat terhadap peristiwa CBM karena pasar bereaksi hanya pada dua spot waktu di sekitar hari peristiwa CBM, hal ini menunjukkan bahwa pasar sudah efisisen bentuk setengah kuat 
Reaksi pasar yang terjadi akibat CBM dapat dijelaskan dengan signalling theory. Peristiwa CBM memberikan sinyal kepada dunia bahwa ekonomi China tidak sekuat yang investor ekspektasikan. Jatuhnya harga saham menjadi momentum yang memberikan sinyal jelas bahwa kondisi perekonomian China sedang tidak baik. China sebagai negara perekonomian terbesar kedua di dunia memiliki pengaruh yang besar terhadap negara lain. China is too big and too deeply wired into the rest of the world's economy for its problems not to be felt outside its borders(Cendrowski, 2015). Investor akhirnya secepat mungkin menarik modalnya di pasar modal sehingga menimbulkan kepanikan.

\section{SIMPULAN DAN SARAN}

Berdasarkan hasilpembahasan kesimpulan yang dapat ditarik adalah sebagai berikut: 1). Hasil penelitian menyatakan bahwa terdapat rata-rata abnormal return yang signifikan pada delapan Indeks Sektoral di Bursa Efek Indonesia yaitu Sektor Pertanian; Aneka Industri; Industri Dasar dan Kimia; Industri Barang Konsumsi; Properti dan Real Estate; Transportasi dan Infrastruktur; Keuangan; dan Perdagangan, Jasa dan Investasi. Hasil ini membuktikan bahwa terdapat reaksi pasar akibat peristiwa China'sblack Monday (CBM) pada delapan sektor tersebut sedangkan pada sektor pertambangan tidak terdapat reaksi pasar akibat peristiwa CBM.Tidak adanya abnormal return diduga diakibatkan banyak investor sudah lebih dulu melindungi asetnya sehingga ketika peristiwa CBM terjadi investor tidak kaget. 
Gde Agung Satria, Luh Gede Sri Hartini, dan Henny Rahyuda. Reaksi Pasar Terhadap....

2). Pengujian kecepatan reaksi menunjukkan bahwa delapan sektor bereaksi cepat terhadap peristiwa CBM karena sektor bereaksi pada dua spot waktu di sekitar periode peristiwa hal ini berarti pasar telah efisien bentuk setengah kuat.

Berdasarkan hasil analisis dan simpulan maka saran yang dapat diberikan untuk investor adalah sebagai berikut: 1). Hasil ini membuktikan bahwa peristiwa China's Black Monday (CBM) berpengaruh pada delapan Indeks Sektoral di Bursa Efek Indonesia. Investor yang berinvestasi di Pasar Modal diharapkan segera melepas sahamnya ketika terjadi peristiwa global seperti peristiwa CBM agar tidak mengalami kerugian yang lebih besar. 2). Investor yang ingin melakukan investasi kembali agar memperhatikan kebijakan yang dilakukan negara tempat terjadinya peristiwa karena kebijakan tersebut akan kembali mempengaruhi pasar modal. Kebijakan yang diambil People Bank of China setelah kejadian CBM telah menyebabkan pasar kembali bereaksi negatif.

\section{REFERENSI}

Afif M, Taftazani., Abdul Kohar Irwanto., dan Eko Rudy Cahyadi. 2015. Dampak Krisis Keuangan Global 2008 terhadap Volatilisas Return Saham Perbankan di BEI.Jurnal Aplikasi Manajemen (JAM), Vol. 13, No. 01

Ahmad, Wasim., Bhanumurthy, N.R., and Sehgal, Sanjay. 2014. The Eurozone Crisis and Its Contagion Effects on The European Stock Markets. Studies in Economics and Finance,31(3):325-352

Aini, Niswah Qurrotul dan Djumahir. 2016. Reaksi Pasar Modal Sebelum dan Sesudah Peristiwa Penguatan Tertinggi Dolar Us Terhadap Rupiah Tahun 2015. Jurnal Ilmiah Mahasiswa FEB Universitas Brawijaya, $4(2)$ 
Angelovska, Julijana. 2011. The Impact of Political Events - "Name Issue" on an Emerging Macedonian Stock Market. Journal of Public Administration and Governance, Vol. 1, No. 2. pp 203-216

Arisyi F. Raz, Tamarind P. K. Indra, Dea K. Artikasih, dan Syalinda Citra. 2012. Krisis Keuangan Global Dan Pertumbuhan Ekonomi: Analisa Dari Perekonomian Asia Timur. Buletin Ekonomi Moneter dan Perbankan , Oktober

BBC. 2015. Usai "Black Monday", Saham-saham Asia Berjatuhan. http://www.bbc.com/indonesia/majalah/2015/08/150825_majalah_sah amasia_berjatuhan (diunduh tanggal 15 November 2016)

Bekaert, Geert., Ehrmann, Michael., Fratzscher, Marcel., and Mehl, Arnaud. 2011. Global Crises and Equity Market Contagion. ECBWorking Paper Series No. 1381

Bloomberg. 2015. China's Stocks Sink Most Since 2007 as State Intervention Fails. https://www.bloomberg.com/news/articles/2015-08-24/chinesestock-index-futures-tumble-after-last-week-s-retreat (diunduh tanggal 20 November 2016)

Bodie, Zvie., Kane, Alex., and Marcus, Alan J. 2014. Manajemen Portofolio dan Investasi. Edisi Kesembilan - Buku 1. Jakarta: Salemba Empat

BPS. 2016a. Nilai Ekspor Menurut Negara Tujuan Utama (Nilai FOB: juta US\$), 2000-2014. https://www.bps.go.id (diunduh tanggal 13 November 2016)

BPS. 2016b. Nilai Impor Menurut Negara Asal Utama (Nilai CIF: juta US\$), 2000-2014. https://www.bps.go.id (diunduh tanggal 13 November 2016)

Cendrowski, Scott. 2015. China's 'Black Monday' as stock market slides 8.5\% http://fortune.com/2015/08/24/chinas-black-monday-as-stockmarket-slides-8-5/ (diunduh tanggal 28 November 2016)

Coppola, Frances. 2015. China's Black Monday Signals The End of Its Growth Cycle. http://www.forbes.com (diunduh tanggal 2 November 2016)

Fahmi, Irham. 2013. Pengantar Pasar Modal. Cetakan Kedua, Bandung : Alfabeta

Ferstl, Robert., Utz, Sebastian., and Wimmer, Maximilian. 2012.The Effect of the Japan 2011 Disaster on Nuclear and Alternative Energy Stocks Worldwide: An Event Study. BuR - Business Research, 5(1):25-41 
Gde Agung Satria, Luh Gede Sri Hartini, dan Henny Rahyuda. Reaksi Pasar Terhadap....

Fortune. 2015. China's 'Black Monday' as stock market slides $8.5 \%$. http://fortune.com/2015/08/24/chinas-black-monday-as-stock-marketslides-8-5/ (diunduh tanggal 29 November 2016)

Goodell, John W and Bodey, Richard A. 2012. Price-Earnings Changes During US Presidential Election Cycles: Voter Uncertainty and Other Determinants. Public Choice, 150:633-650

Gosta, Demis. 2015. Bursa Saham 26 Agustus: Berhasil pertahankan Momentum, Indeks Menguat Naik 0,22\% ke Level 4.237,73. http://market.bisnis.com/bursa-indeks (diunduh tanggal 21 Desember 2016)

Gumanti, A Tatang dan Palupi, Karvina W. 2008. Reaksi Pasar Modal Indonesia Terhadap Krisis Subprime Mortgage Di Amerika Serikat.National Conference on Management Research

Huyghebaert, Nancy and Lihong Wang. 2010. The Co-Movement Of Stock Markets In East Asia Did The 1997-1998 Asian Financial Crisis Really Strengthen Stock Market Integration?. China Economic Review, 21: 98-112

IDX. 2016. Profil Perusahaan Tercatat. http://www.idx.co.id/id$\underline{\mathrm{id} / \text { beranda/perusahaantercatat/profilperusahaantercatat.aspx }}$ (diunduh tanggal 20 November 2016)

Independent. 2015. China's Black Monday explained: What is it - and how will it affect you?. http://www.independent.co.uk (diunduh tanggal 10 November 2016)

Jain, Priyanka., Vyas, Vishal., and Roy, Ankur. 2013. A Study on Weak Form of Market Efficiency During The Period of Global Financial Crisis in The Form of Random Walk on Indian Capital Market. Journal of Advances in Management Research, Vol. 10, No. 01. pp 122-138

Jogiyanto H,M. 2010. Teori Portofolio dan Analisis Investasi. Edisi Keenam. Yogyakarta: BPFE-Yogyakarta.

Joshipura, Mayank dan Nusrathunnisa. 2013.Market Reaction to Bonus Announcement in Post Global Financial Crisis Era: Evidence from India. Asian Journal of Finance \& Accounting,5(2):256-267

Khajar, Ibnu. 2015. The Global Stock Exchange and Its Influence Toward The Indonesia Stock Exchange After The Global Financial Crisis in 2008. The International Journal of Organizational Innovation, 8(1):133-154 
Kumar, Sanjay and Liu, Jiangxia. 2013. Impact of Terrorism on International Stock Markets. The Journal of Applied Business and Economics, 14(4):42-60

Luchtenberg, Kimberly F and Seiler, Michael J. 2014. Did the Recent Financial Crisis Impact Integration between the Real Estate and Stock Markets?. Journal of Real Estate Portfolio Management Vol. 20, No.1, pp 1-20

Mackinlay. A. Craig. 1997. Event Studies in Economics and Finance.Journal of Economic Literature, 35:13-39

Mahmood, Faiq., Xia, Xinping., Ali, Mumtaz., Usman, Muhammad., and Shahid, Humera. 2011. How Asian and Global Economic Crises Prevail in Chinese IPO and Stock Market Efficiency. International Business Research, 4(2):226-237

Nezky, Mita. 2013. Pengaruh Krisis Ekonomi Amerika Serikat terhadap Bursa Saham dan Perdagangan Indonesia. Buletin Ekonomi Moneter dan Perbankan, Januari

Prasojo, Hariyo Subekti Utomo. 2012. Reaksi Pasar Saham Terhadap Pengumuman Krisis Finansial Global (Studi pada Perusahaan Pertambangan yang Masuk Dalam LQ45). Jurnal Ilmiah Mahasiswa FEB Universitas Brawijaya, 1(2)

Ramiah, Vikash. 2012. Effects of the Boxing Day Tsunami on the World Capital Markets. SpringerRev Quant Finan Acc (2013) 40, pp 383-401

Ranjeeni. K and Sharma S. S. 2015. The Impact of the Lehman Brothers' Bankruptcy on the Performance of Chinese Sectors. Financial Econometrics Series SWP 2015/15

Setiawan, Sigit. 2012. Asean-China FTA: Dampaknya Terhadap Ekspor Indonesia dan Cina. Buletin Ilmiah Litbang Perdagangan,6(2)

Siwi, Arisa P. 2013. Bilateral Free Trade: Hubungan Perdagangan IndonesiaChina dalam Kerangka ACFTA. Jurnal Analisis Hubungan Internasional, 2(3):111-127

Sukirno. 2015. Devaluasi Yuan dan Dampak Jangka Panjang Bagi Indonesia. http://market.bisnis.com/read/20150813/191/462279/devaluasi-yuandan-dampak-jangka-panjang-bagi-indonesia (diunduh tanggal 21 Desember 2016)

Time. 2015. Global Markets Hammered as Dow Plunges Over 1,000 Points. http://time.com (diunduh tanggal 12 November 2016) 
Gde Agung Satria, Luh Gede Sri Hartini, dan Henny Rahyuda. Reaksi Pasar Terhadap....

Trihadmini, Nuning. 2011. Contagion Dan Spillover Effect Pasar Keuangan Global Sebagai Early Warning System. Finance and Banking Journal, Vol. 13, No. 01

Viva. 2011. Komoditas RI yang Jadi Incaran China. http://bisnis.news.viva.co.id/news/read/252178-komoditas-ini-bakaljadi-incaran-china (diunduh tanggal 3 Desember 2016)

Walker, Andrew. 2015. Mengapa Penurunan Saham Cina Mempengaruhi Dunia ?. http://www.bbc.com (diunduh tanggal 7 November 2016)

World Bank. 2016. China Overview. http://www.worldbank.org/en/country/china/overview tanggal 8 November 2016)

Zainuddin, Muhammad. 2016. Reaksi Pasar Modal Terhadap Pengumuman Gagal Bayar Hutang Yunani Pada Saham-Saham LQ-45 (Event Study Krisis Keuangan Yunani Pada Tahun 2015). Jurnal Ilmiah Mahasiswa FEB Universitas Brawijaya, Vol. 04, No. 02 